\author{
ANNALS OF THE \\ UNIVERSITY OF CRAIOVA
}
Series: $\checkmark$ Biology
$\checkmark$ Horticulture
$\checkmark$ Food products processing technology
$\checkmark$ Environmental engineering

\title{
Vol. XXVI (LXII) - 2021 \\ RESPONSE OF SOME POTATO CLONES WITH POTENTIAL RESISTANCE TO LATE BLIGHT DISEASE (PHYTOPHTHORA INFESTANS) UNDER FIELD CONDITIONS
}

\author{
Hermeziu Radu ${ }^{1}$, Hermeziu Manuela ${ }^{1 *}$ \\ ${ }^{1}$ National Institute of Research and Development for Potato and Sugar Beet Brasov (Romania) \\ ${ }^{*}$ Corresponding author, e-mail: hermezium@gmail.com
}

Keywords: potato, Phytophthora infestans, Solanum, breeding, resistance

\begin{abstract}
In the present study thirteen potato clones were evaluated for resistance against late blight caused by Phytophthora infestans. Field experiment was conducted to NIRDPS Brasov, Romania, under natural epiphytotic conditions. The first symptoms of potato late blight disease were observed at 58 days after planting on Sasa $\times$ Pamela and R7Sasa $\times$ Orchestra clones. Out of 13 genotype, the incidence showed 2 genotpyes (Sasa R3 x Oceania and Sasa R7x Orchestra) as highly susceptible, 2 varieties as moderately susceptible (Agria x Rustic (Cl1) and Agria $\times$ Rustic (Cl2)), 1 genotype as susceptible (Sasa $x$ Pamela), 5 genotpyes relatively resistant (Sasa R3 x Rustic (Cl2), Sasa (R3) x Rustic (Cl3), Sasa (R3) x Orchestra, Sasa (R8) $x$ Orchestra) Sasa (R6) $x$ Orchestra) and 3 genotpys resistant (Sasa (R3) $x$ Rustic (Cl1), Sasa $x$ Fribel, Sasa $x$ Florice). The Area under the disease progress curve (AUDPC) value was less for R3Sasa x Rustic, Sasa $\times$ Fribel and Sasa x Florice compared to other clones, indicating their higher level of resistance.
\end{abstract}

\section{INTRODUCTION}

Potato cultivation involves huge efforts. A classic breeding program often begins with 100,000 seedlings and ends with two or three varieties in more than 10 years (Bradshaw and Mackay, 1994). Potato, after wheat and rice, it is the third crop in order of consumption. The largest areas of potatoes are found in Asia and Europe.

There are two main challenges in its cultivation:

1. the crop multiplies vegetatively and a healthy seed is needed; to be grown in an area and/or period of the year free of insect vectors of viruses (aphids) in order to be productive;

2. the culture is not resistant to its main enemy: the late blight produced by the fungus Phytophthora infestans.

Potato late blight caused by the pathogen Phytophthora infestans first occured in 1840 in Belgium being imported from the Toluca Valley in Mexico which was thought to be its centre of origin. The disease spred rapidly to The Netherlands, France, Britain and Ireland, where was responsable for the Great Famine (18481848) (Bourke, 1964, Colon et al., 1995).

Under conducive climatic conditions, it takes only two days to destroy potato field (Sajid et al., 2019). Late blight association with secondary pathogens and soft 
rotting bacteria can conduct to severe disease of tuber blight (2-5\%) that can lead to complete loss of potatoes in storage (Dalsgaard and Pedersen, 1996).

Two type of resistance against late blight have been described in potato: qualitative resistance and quantitative resistance (Rauscher et al., 2010).

Late blight qualitative resistance is governed by resistance $(R)$ genes that encode immunity through a hypersensitive reaction and is thought to be monogenic, specific and often of short durability due to the high genetic variability of the pathogen. Since the early part of the last century breeding activities have mainly focused on the high level of resistance conferred by dominant major $R$ genes from the Mexican hexaploid wild Solanum species, Solanum demissum. Presently, many cultivars with S. demissum in their pedigree are available (Hajianfar et al., 2014).

Sixty-three resistance genes to $P$. infestans have been identified from various Solanum species and out of them twenty-seven have already been cloned (Rodewald and Trognitz, 2013). Eleven major resistance genes (R1-R11) which derive from the hexaploid wild potato species $S$. demissum (Black et al., 1953; Malcolmson, 1969) were identified and have been introgressed into cultivated potato (Gebhardt and Valkonen, 2001). These resistance genes are race-specific, thus they provide non-durable resistance and are rapidly overcome by virulent strains of the pathogen (Malcolmson and Black, 1966). From the S. demissum-derived R genes four have been cloned and analyzed. These are R1 (Ballvora et al., 2002), R2 (Lokossou et al., 2009), R3a (El-Kharbotly et al., 1996; Huang et al., 2005) and R3b (Li et al., 2011) Recently, Rpi genes were identified in the diploid wild potato species S. bulbocastanuml, and some of them were cloned. These cloned genes are the Rpiblb1 also known as RB (Song et al., 2003), the Rpi-blb2 (Vossen et al., 2005), the Rpi-blb3 and the Rpi-bt1 (Oosumi et al., 2009). Another Rpi gene which possibly derives from S. bulbocastanum is the Rpi-abpt (Lokossou et al. 2009), that was isolated from a complex quadruple hybrid of $S$. acaule Bitter. S. bulbocastanum, $S$. tuberosum group Phureja and S. tuberosum (Park et al., 2005).

With the possibility of sexual recombination, genetic diversity has increased among the descendants of the pathogen, which causes difficulties in controlling late blight. In addition, the development of fungicide resistance in Phytophthora populations requires more frequent applications during the growing season to control the disease, causing contamination with a negative impact on the environment and human health (Grünwald et al.,2001).

\section{MATERIAL AND METHODS}

Experiments were carried out at the National Institue of Research and Development for Potato and Sugar Beet Brasov, Romania, on a cambic chernozeum soil, with $6.7 \mathrm{pH}$, humus $4.68 \%$ and clay $27 \%$. The pre-crop was wheat and for current fertilizer was used $1000 \mathrm{~kg} / \mathrm{ha} \mathrm{N}: \mathrm{P}: \mathrm{K}: 15: 15: 15+\mathrm{S}$.

Planting distance was $75 \mathrm{~cm}$ between rows and $30 \mathrm{~cm}$ between plants per row, having 4 rows with 10 plants each one. Planting was done manually in May 3, 2021.

During the vegetation were applied the usual maintenance works (hilling, herbicides), including three treatments for Colorado beetle unless late blight control with fungicides.

The biological material was represented by some varieties (Orchestra, Pamela, Florice, Rustic, Fribel) and genotypes with gene (R3, R6, R7, R8) with specific field resistance to late blight. 
Observations were performed from the beginning of July to the middle of August once in 7-10 days.

Disease incidence was recorded by counting of plants that showing visible symptoms of late blight and the data were expressed as a percentage of the total assessed plants. The disease incidence was calculated with the following formula: plot) $\times 100$

Disease incidence $=($ Number of diseased plant/total number of plant on a

Because late blight is a polyciclic disease it is recommanded to use the Area under the disease progress curve (AUDPC) to mesure resistance (Fry, 1978), using the formula (Campell and Madden, 1990):

$$
\mathrm{AUDPC}=\sum_{i=1}^{n-1}\left[\frac{\mathrm{X} i+\mathrm{Xi}+1}{2}\right](t i+1-t i)
$$

, where "t" is the time of each reading, , $y$ ' is the percent of affected foliage at each reading and , $n$ ' is the number of readings. The variable ,t' represent, in our case, the days after planting.

\subsection{Meteorological data}

\section{RESULTS AND DISCUSSIONS}

April month was colder than normal, with minimum negative air temperatures recorded for 10 consecutive days. Negative values were also recorded at ground level. The amount of precipitation that fell in April was $39.2 \mathrm{~mm}$, which is $10.8 \mathrm{~mm}$ lower than the MAA. In May, the air temperature was lower by $1.3^{\circ} \mathrm{C}$ compared to the multiannual average, and the amount of precipitation was lower by $4.97 \mathrm{~mm}$ compared to the MAA value. June was a rainy month $(106,1 \mathrm{~mm})$, with precipitation in the first two decades even daily and with slightly higher temperatures than average $\left(+0.8^{\circ} \mathrm{C}\right)$. in July the situation changed completely, registering much higher temperatures $\left(+2.9^{\circ} \mathrm{C}\right)$ and a lower level of precipitation, by $28.7 \mathrm{~mm}$ compared to the multiannual average (Figure 1 and 2).

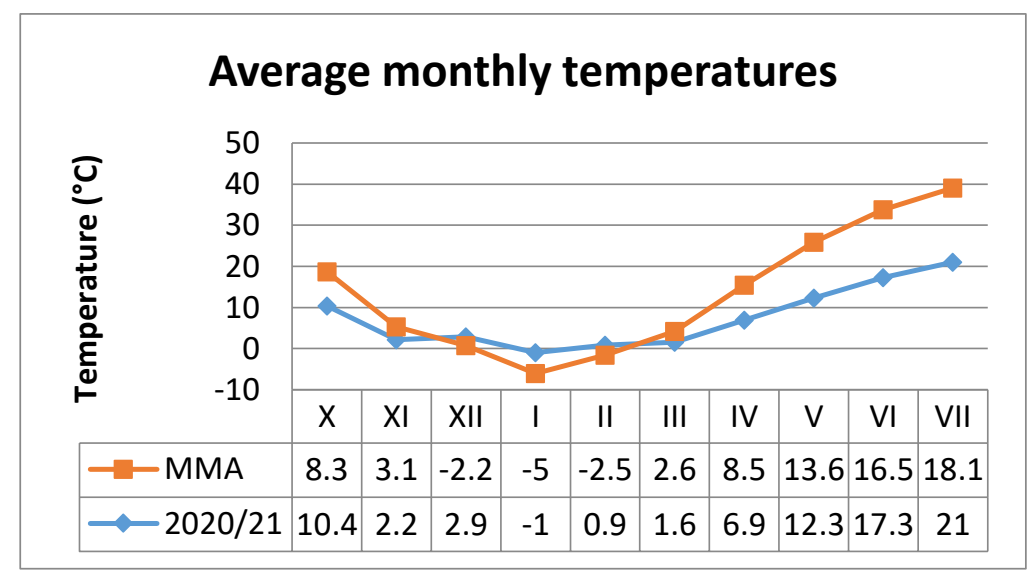

Figure 1 . Monthly temperature average 


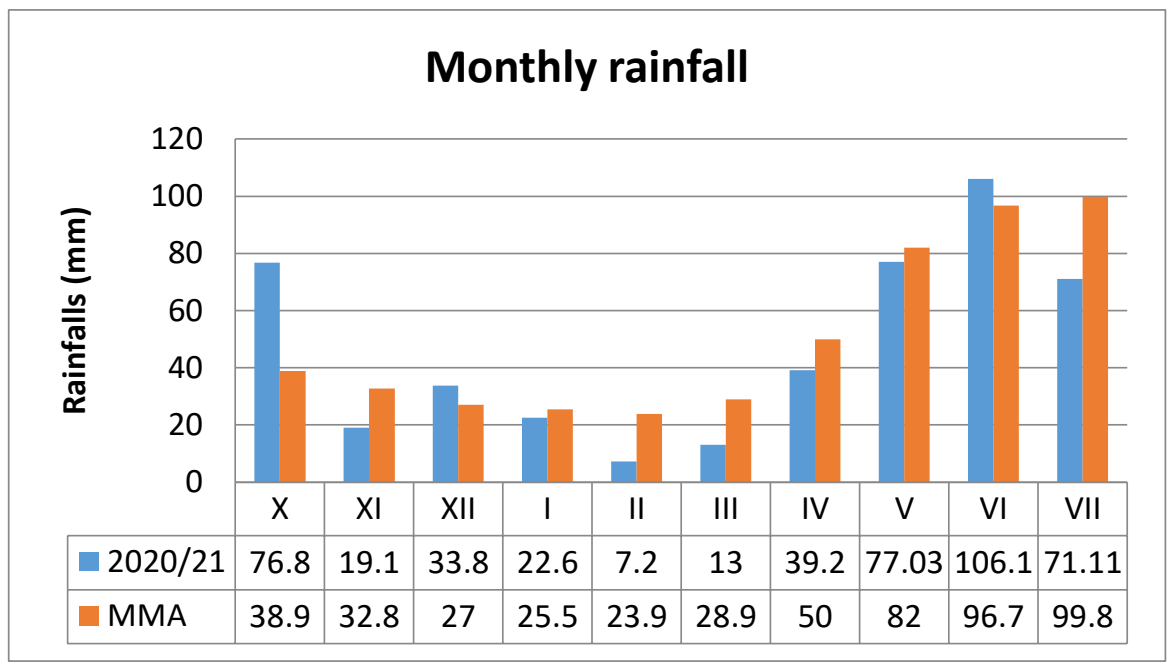

Figure 2. Monthly rainfall amount

Late blight is one of the most dangerous diseases of potato worlwide and cause significant yield loss. The pathogen is highly variable and adapt to the newly bred varieties and fungicides. The enviromental conditions decisively influence the resistance of varieties to late blight attack. In order to obtain conclusive results, the behavior towards the presence of the pathogen is studied both temporally (for several years) and spatially (same varieties in different locations), because not all varieties adapt to different environmental conditions. (AUDPC)

1.2. Disease incidence and Area under disease progress curve

The first symptoms of potato late blight disease were observed at 58 days after planting (DAP) on Sasa $\times$ Pamela and Sasa (R7) $\times$ Orchestra clones. The symptoms had appear on lower leaves, having light-to-dark green color and circular to irregularly shaped. In literature Pamela variety is considered like a resistant variety to foliage late blight, but with fairly low tuber resistance. Orchestra variety is considered moderately susceptible. It is noted that although one of the parents has a clearly defined resistance, under specific field conditions, it can be compromised. $P$. infestans rapidly overcome $R$ genes and limits the durability of any single $R$ gene. As a result, the $R$ genes intro-gressed from $S$. demissum to the current clones have been overcome as new pathogen strains evolve that are virulent on the previously resistant hosts.

Disease incidence of the studied clones showed statistically significant difference at $5 \%$ level of significance. Out of 13 genotypes, the incidence showed 2 genotpyes (Sasa R3 $\times$ Oceania and Sasa R7 x Orchestra) as highly susceptible, 2 genotpyes as moderately susceptible (Agria $\times$ Rustic $(\mathrm{Cl} 1)$ and Agria $\times$ Rustic (Cl2)), 1 genotpye as susceptible (Sasa $x$ Pamela), 5 genotpyes relatively resistant (Sasa R3 x Rustic (Cl2), Sasa R3 x Rustic (Cl3), Sasa (R3) x Orchestra, Sasa (R8) $x$ Orchestra) Sasa (R6) $x$ Orchestra) and 3 genotpyes resistant (Sasa (R3) x Rustic (Cl1), Sasa x Fribel, Sasa x Florice) (Figure 3). 


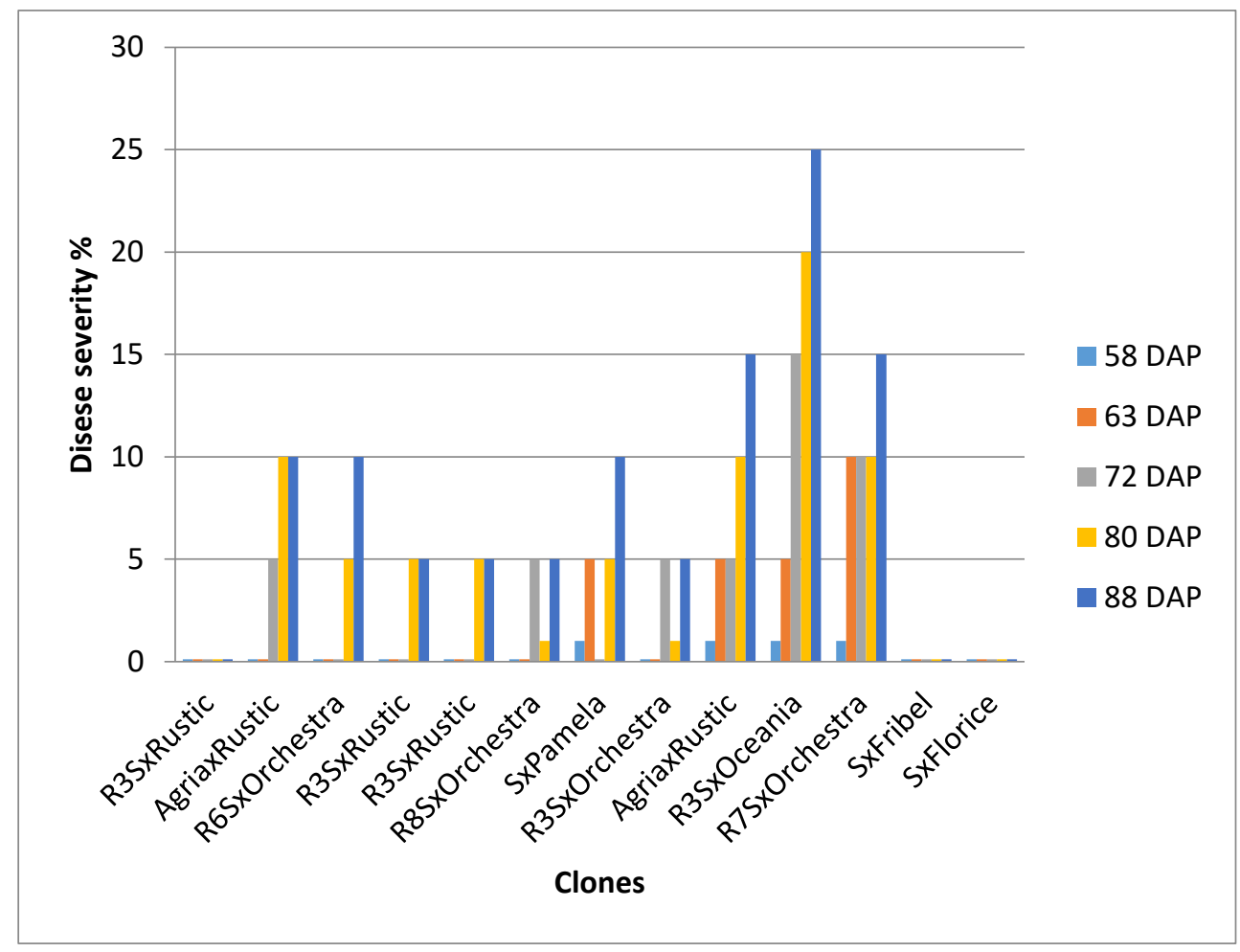

Figure 3. Disease severity (\%) recorded

AUDPC estimates the area under the disease progress curve. This value is expressed as \% - days, that is, the sum of non transformed daily percentage values of infection. Highest values will correspond to more susceptible and lowest values will correspond to more resistant genotpyes (Table 1).

Table 1.

Area under disease progress curve (AUDPC) of late blight on 13 potato clones cultivated to NIRDPSB Brasov in 2021

\begin{tabular}{|c|c|c|}
\hline No. & Potato clones & $\begin{array}{l}\text { Area under disease progress curve } \\
\text { (AUDPC) value }\end{array}$ \\
\hline 1 & Sasa (R3) x Rustic (Cl1) & 3 \\
\hline 2 & Agria x Rustic (Cl 1) & 163 \\
\hline 3 & Sasa (R6) x Orchestra & 77 \\
\hline 4 & Sasa (R3) x Rustic (Cl2) & 62 \\
\hline 5 & Sasa (R3) x Rustic (Cl3) & 62 \\
\hline 6 & Sasa (R8) $\times$ Orchestra & 71 \\
\hline 7 & Sasa x Pamela & 118 \\
\hline 8 & Sasa (R3) x Orchestra & 71 \\
\hline 9 & Agria $\times$ Rustic (Cl 2) & 184 \\
\hline
\end{tabular}




\begin{tabular}{|r|r|r|}
\hline 10 & Sasa (R3) x Oceania & 425 \\
\hline 11 & Sasa (R7) Orchestra & 298 \\
\hline 12 & Sasa x Fribel & 3 \\
\hline 13 & Sasa x Florice & 3 \\
\hline
\end{tabular}

High level of AUDPC (425) were observed on Sasa (R3) x Oceania, which can be associated with the favorable environmental conditions registered in the first period of vegetation from this year. The lowest AUDPC (3) levels were observed to Sasa (R3) x Rustic (Cl1), Sasa x Fribel and Sasa x Florice clones.

The AUDPC value obtained was less for clones Sasa (R3) x Rustic (Cl1), Sasa $\times$ Fribel and Sasa $\times$ Florice compared to other clones, indicating their higher level of resistance. In the beginning, the increase of disease on all clones was slower however, afterwards the disease increase on clones Sasa (R3) $x$ Oceania and Sasa (R7) $x$ Orchestra was highly fast followed by both Agria $\times$ Rustic (Cl1) and (Cl2), but slower in Sasa (R6) x Orchestra, Sasa (R8) x Orchestra and Sasa (R3) x Orchestra.

\section{CONCLUSIONS}

Clones resistance with a fungicides correct strategy are the efficient solution to control late blight. The current assessment provides information on adaptability to specific environmental conditions, being predominantly influenced by location and season.

In the current study, three clones, Sasa (R3) x Rustic, Sasa $x$ Fribel and Sasa $x$ Florice exhibited the highest levels of resistance to late blight under field conditions.

The level of resistance of the tested clones can help the breeder to select materials which contain genes against the pathogen (major $\mathrm{R}$ genes and/or minor resistance genes) and assure the posibility to introduce them in new cultivars to reach highest and durable levels of resistance.

\section{ACKNOWLEDGMENT}

The paper is part of the Project PN 19-32-01-01/2019, funded by Ministry of Research, Innovation and Digitization - Romania.

\section{REFERENCES}

Bourke P.M.A. 1964. Emergence of potato blight, 1843-46. Nature, 203, 805-808. Ballvora A., Ercolano M.R., Weiß J., Meksem K., Bormann, C.A., Oberhagemann P., Salamini F., Gebhardt, C. 2002. The R1 gene for potato resistance to late blight (Phytophthora infestans) belongs to the leucine zipper/NBS/LRR class of plant resistance genes. The Plant Journal 30, 361-371.

Black W., Mastenbroek C., Mills W.R., Peterson, L.C. 1953. A proposal for an international nomencla-ture of races of Phytophthora infestans of genes controlling immunity in Solanum demissum derivatives. Euphytica 2, 173-240.

Bradshaw J.E. and Mackay G.R. 1994. Potato Genetics. Wallingford, Oxfordshire: CAB International.

Campbell C.L. and Madden, L.V. 1990. Introduction to plant disease epidemiology. Wiley, New York, USA, pp. 532. 
Colon L.T., Turkensteen L.J., Prummel W. 1995. Durable resistance to late blight (Phytophthora infestans) in old potato cultivars. Eur J Plant Pathol 101, 387$397 \mathrm{https}: / /$ doi.org/10.1007/BF01874852.

Dalsgaard A. and Pedersen F.K., 1996. Shirlan, a new fungicide against potato late blight, $13^{\text {th }}$ Danish Plant Protection Conference Pests and Disease Planteavlsforsog, 65-75.

El-Kharbotly A., Palomino-Sanchez C., Salamini F., Jacobsen E., Gebhardt, C.1996. R6 and R7 alleles of potato conferring race-specific resistance to Phytophthora infestans (Mont.) de Bary identified genetic loci clustering with the R3 locus on chromosome XI. Theor. Appl. Genet. 92, 880-884.

Fry W.E. 1978. Quantification of general resistance of potato cultivars and fungicide effects for integrated control of potato late blight. Phytopathology 68, 1650-1655.

Gebhardt C. and Valkonen J. P., 2001. Organization of genes controlling disease resistance in the potato genome. Annu. Rev. Phytopathol. 39, 79-102.

Grünwald N.J., Flier W.G., Sturbaum A.K., Garay-Serrano E., Van den Bosh T.B.M., Smart C.D., Matuszak J.M., Lozoya-Saldan`a H., Turkensteen L.J., Fry, W.E. 2001. Population structure of Phytophthora infestans in the Toluca valley region of central Mexico. Phytopathology 91: 882-890.

Hajianfar R.,. Polgár Z., Wolf I.,. Takács A., Cernák I., Taller J. 2014. Complexity of late blight resistance in potato and its potential in cultivar improvement. Acta Phytopathologica et Entomologica Hungarica 49 (2), 141-161 DOI: 10.1556/APhyt.49.2014.2.2.

Huang S., Van Der Vossen E. A. G., Kuang H., Vleeshouwers V.G.A.A., Zhang N., Borm T.J. A., Van Eck H.J., Baker B., Jacobsen E., Visser, R.G.F. 2005. Comparative genomics enabled the isolation of the R3a late blight resistance gene in potato. The Plant Journal 42, 251-26.

Li G., Huang S., Guo X., Li Y., Yang Y., Guo Z., Kuang H., Rietman H., Bergervoet M., Vleeshouwers V. 2011. Cloning and characterization of R3b; members of the R3 superfamily of late blight resistance genes show sequence and functional divergence. Mol. Plant Microbe Int. 24,1132-1142.

Lokossou A.A., Park T.H., van Arkel G., Arens M., Ruyter-Spira C., Morales J., Whisson S.C., Birch P.R., Visser R.G., Jacobsen E. 2009. Exploiting knowledge of R/Avr genes to rapidly clone a new LZ-NBS-LRR family of late blight resistance genes from potato linkage group IV. Mol. Plant Microbe Int. 22, 630-641.

Malcolmson J. and Black W. 1966. New R genes in Solanum demissum Lindl and their complementary races of Phytophthora infestans (Mont.) de Bary. Euphytica 15, 199-203.

Malcolmson J., 1969. Races of Phytophthora infestans occurring in Great Britain. Trans. Br. Mycol. Soc. 53, 417-423.

Oosumi T., Rockhold, D., Maccree, M., Deahl, K., McCue, K. and Belknap, W. 2009. Gene Rpi-bt1 from Solanum bulbocastanum confers resistance to late blight in transgenic potatoes. Am. J. Potato Res. 86, 456-465

Rauscher et al 2010 Rauscher G., Simko I., Mayton H., Bonierbale M., Smart C.D., Grünwald N.J., Greenland A., Fry W.E. 2010. Quantitative resistance to late blight from Solanum berthaultii cosegregates with RPi-ber: insights in stability through isolates and environment. Theor Appl Genet 12, 1553-1567. 
Rodewald J. and Trognitz B. 2013. Solanum resistance genes against Phytophthora infestans and their corresponding avirulence genes. Molecular Plant Pathology 14, 740-757.

Park,T., Vleeshouwers,V., Huigen D., Van Der Vossen E., Van Eck H., Visser, R. 2005. Characterization and high-resolution mapping of a late blight resistance locus similar to R2 in potato. Theor. Appl. Genet. 111, 591-597.

Sajid A.R., Rehman A., Naqvi H., Umar U., Sherwani H.K., Sherwani M.R. 2019. Identification of sources of resistance and biochemical management of late blight of potato (Phytophthora infestans). Plant Protection 03 (03), 141-150 DOI : 10.33804/pp.003.03.0131

Song J., Bradeen J.M., Naess S.K., Raasch J.A., Wielgus S.M., Haberlach G.T., Liu J., Kuang H., Austin-Phillips S., Buell C.R. 2003. Gene RB cloned from Solanum bulbocastanum confers broad spectrum resistance to potato late blight. P. Natl. Acad. Sci. USA 100, 9128-9133.

Vossen E.A., Gros J., Sikkema A., Muskens M., Wouters D., Wolters P., Pereira A., Allefs, S. 2005. The Rpi blb2 gene from Solanum bulbocastanum is an Mi-1 gene homolog conferring broad spectrum late blight resistance in potato. The Plant Journal 44, 208-222. 